\title{
In Silico Studies of Sesquiterpene Lactones from Vernonia amygdalina Delile on the Expression of EGFR and VEGFR as a New Anticancer Potential
}

\author{
N Nerdy ${ }^{1, *}$, P Lestari' ${ }^{1}$, F Fahdi' ${ }^{1}$ EDL Putra ${ }^{2}$, SAB Amir ${ }^{2}$, F Yusuf ${ }^{3}$, TK Bakri ${ }^{4}$
}

\author{
N Nerdy ${ }^{1, *}$, P Lestari', F Fahdi', \\ EDL Putra ${ }^{2}$, SAB Amir ${ }^{2}$, F Yusuf 3 , TK \\ Bakri $^{4}$
}

'Department of Pharmacy, Faculty of Pharmacy, Institut Kesehatan Deli Husada Deli Tua, Deli Tua Timur, Deli Tua, Deli Serdang, Sumatera Utara, INDONESIA. 2Department of Pharmacy, Faculty of Pharmacy, Universitas Sumatera Utara, Padang Bulan, Medan Baru, Medan, Sumatera Utara, INDONESIA. ${ }^{3}$ Department of Pharmacy, Sekolah Tinggi IImu Kesehatan Arjuna, Pintubosi, Laguboti, Toba Samosir, Sumatera Utara, INDONESIA. ${ }^{4}$ Department of Pharmacy, Faculty of Mathematics and Natural Sciences, Universitas Syiah Kuala, Kopelma Darussalam, Syiah Kuala, Banda Aceh, Aceh, INDONESIA.

\section{Correspondence}

N Nerdy

Department of Pharmacy, Faculty of Pharmacy, Institut Kesehatan Deli Husada Deli Tua, Deli Tua Timur, Deli Tua, Deli Serdang, Sumatera Utara, INDONESIA.

E-mail: nerdy190690@gmail.com

History

- Submission Date: 02-12-2021;

- Review completed: 18-12-2021;

- Accepted Date: 03-01-2022.

DOI : 10.5530/pj.2022.14.13

Article Available online

http://www.phcogj.com/v14/i1

\section{Copyright}

(C) 2022 Phcogj.Com. This is an openaccess article distributed under the term of the Creative Commons Attribution 4.0 International license.

\begin{abstract}
Objective: To assess the inhibition activity of sesquiterpene lactones from Vernonia amygdalina Delile as a new anticancer potential on the expression of cancer therapeutic target-proteins, namely: epidermal growth factor receptor (EGFR), and vascular endothelial growth factor receptor (VEGFR). Methods: The in silico screening, target-based approach (docking) was performed by the Prediction of Activity Spectra for Substances (PASS) website and AutoDock Vina program. The therapeutic cancer target proteins model of EGFR and VEGFR were downloaded from Research Collaboratory for Structural Bioinformatics (RCSB) protein data bank (PDB) with $5 \mathrm{HG} 7$ and $4 \mathrm{AG} 8$ as their respective codes. Results: The test compounds have anticancer activity as predicted by the Prediction of Activity Spectra for Substances (PASS) website and AutoDock Vina program. The molecular docking analysis of the test compounds showed strong interactions and good inhibition activity with the targeted proteins with a low docking score value predicted by the AutoDock Vina program. Conclusion: The test compounds have the potential to be used in anticancer drugs through the inhibitory qualities of EGFR and VEGFR.
\end{abstract}

Key words: In silico, Sesquiterpene lactones, EGFR, VEGFR, Vernonia amygdalina Delile.

\section{INTRODUCTION}

With millions of deaths in 2020, cancer is one of the top causes of mortality worldwide. Around half of all cancer deaths each year are caused by lung, colorectal, liver, and stomach cancers. ${ }^{1}$ Every year, roughly 9 million fatalities and up to 14 million new cases of cancer are recorded worldwide. ${ }^{2}$ According to the American Cancer Society, the estimated number of new cancer cases in 2021 was about 2 million, while there were an estimated 1 million cancer deaths in the United States. ${ }^{3}$ Thus, any work bringing us closer to more effective treatment is vitally important.

Targeted therapy is very crucial in order to comprehend cancer therapy. Protein kinase is usually a key protein involved in targeted cancer therapy. ${ }^{4}$ Radiation therapy, surgery, and systemic chemotherapy are the most common cancer treatments, but are more likely to have clinical efficacy limitations. For example, radiation therapy frequently causes indirect damage to surrounding tissues, resulting in wound complications and surgery that heals poorly; it also may cause microscopic and metastatic disease. Chemotherapy frequently causes systemic toxicity and the development of cancer. ${ }^{5}$ Therefore, there is reason to create a better clinical agent with more targeted activities and a lower risk, as well as the ability to reduce adverse effects. Thus, medicines that target more specific tumorigenic pathways are being developed. In this case, the epidermal growth factor receptor (EGFR) and vascular endothelial growth factor receptor (VEGFR) are the main focus for this study.

The EGFR expression in cancer is associated with disease aggressiveness. The activation of
EGFR stimulates tumor growth and progression through several mechanisms, namely promoting proliferation, angiogenesis, invasion, metastasis and inhibiting apoptosis, adhesion and differentiation. Therefore, EGFR is a rational target for antitumor strategies. ${ }^{6}$ The expression of transcription, mutation and/or gene amplification may be the cause of EGFR activation in tumor cells. The increased protein and transcribed levels of EGFR will correspond to poor prognosis in several cancers such as lung cancer and colorectal cancer. ${ }^{7}$

The VEGFR is known to have a major contribution to angiogenesis. In vitro experiments on capillary endothelial cells have shown that VEGFR is a potential stimulator of angiogenesis because its presence as a growth factor causes endothelial cell proliferation and migration, and even tube formation in capillary junctions. ${ }^{8}$ VEGFR has multiple immediate effects on cancer cells. ${ }^{9}$ Stimulation of VEGFR signaling could enhance cancer cell growth by being involved in the angiogenesis process which requires solid tumor growth. ${ }^{10}$

Natural products, medicinal plants, and plantbased foods have their own role in the prevention, treatment, and management of cancer. ${ }^{11}$ Plants containing secondary metabolites such as alkaloids, flavonoids, saponins, terpenoids, and steroids have shown good anticancer activity in vitro and in vivo. ${ }^{12}$ The Vernonia amygdalina Delile is a plant that has many antimicrobial, antidiabetic, antimalarial, and anticancer properties. ${ }^{13}$ Several medicinal plants have played a part in cancer prevention, treatment, and management. Plants are a great and consistent source of new anticancer medicines, estimated to be used in more than $60 \%$ of all existing anticancer drugs. ${ }^{14}$
Cite this article: Nerdy N, Lestari P, Fahdi F, Putra EDL, Amir SAB, Yusuf F, et al. In Silico Studies of Sesquiterpene Lactones from Vernonia amygdalina Delile on the Expression of EGFR and VEGFR as a New Anticancer Potential. Pharmacogn J. 2022;14(1): 91-97. 
Various active compounds isolated have shown to have anticancer and cytotoxic properties. The sesquiterpene lactones play a main role in the anticancer effect. ${ }^{15}$ Preliminary study of pharmacokinetic properties and toxicity properties by in silico show good results in absorption, distribution, metabolism, excretion, and toxicity. ${ }^{16}$ Despite this encapsulating research, there is no study on molecular interactions between phytoconstituents and proteins implicated in angiogenesis of cancer. Therefore, molecular interactions with EGFR and VEGFR were investigated in this study using in silico prediction.

\section{MATERIALS AND METHODS}

\section{Materials}

The computer used in this study were Omen laptop by Hewlett Packard operating with a Windows 10 system, Intel $^{\circledR}$ Core $^{\text {tw }}$ i7 $7-7700 \mathrm{HQ}$ processor, $2.81 \mathrm{GHz}$ speed, and $8 \mathrm{~GB}$ random access memory.

The software used were the AutoDock Vina program version 4.2, Biovia Discovery Studio Visualizer program version 17.2.0.16349, ChemDraw program version 19.1, and Prediction of Activity Spectra for Substances (PASS) website (http://www.way2drug.com/PASSOnline/index.php).

The molecular structures of the test compounds were vernodalol, vernodalin, vernolepin, vernomygdin, vernolide, and hydroxyvernolide. Also used were standard compounds. Cyclophosphamide was obtained from PubChem website (https://pubchem.ncbi.nlm.nih.gov) in the Simplified Molecular Input Line Entry System (SMILES) format.

The crystal structures of EGFR and VEGFR were obtained from Research Collaboratory for Structural Bioinformatics (RCSB) protein data bank (PDB) website (http://www.rcsb.org/pdb) with protein data bank (PDB) codes of 5HG7 and 4AG8, respectively.

\section{Methods}

The preliminary screening for pharmacological activity of test compounds, namely: vernodalol, vernodalin, vernolepin, vernomygdin, vernolide, and hydroxyvernolide also with standard compound, namely: cyclophosphamide were done by inserted the Simplified Molecular Input Line Entry System (SMILES) of the compounds to Prediction of Activity Spectra for Substances (PASS) website. ${ }^{17}$

The three dimensional crystal structures of human EGFR and human VEGFR with their own native ligands were retrieved from the Research Collaboratory for Structural Bioinformatics (RCSB) protein data bank (PDB) websitewith protein data bank (PDB) codes of 5HG7 and 4AG8. The native ligands were 630 for human EGFR and AXI for human VEGFR. The consisting natural residues were separated from the proteins using the Biovia Discovery Studio Visualizer. ${ }^{18}$ The protein structures were cleaned, water molecules were removed, polar hydrogens were added, Gasteiger charges were calculated, and nonpolar hydrogens were merged by AutoDock Vina. ${ }^{19}$

Validation by redocking of the native ligand was performed using AutoDock Vina. The docking simulations were performed, resulting in 10 different conformations of the ligands interacting with the receptor, which were ranked by the value of binding energy. The root mean square deviation (RMSD) of the conformation that gives the lowest binding energy was further calculated by overlapping the native ligand initial conformation and the native ligand redocking conformation. ${ }^{20}$

The test compounds were vernodalol, vernodalin, vernolepin, vernomygdin, vernolide, and hydroxyvernolide and the standard compound was cyclophosphamide. The analysis of these compounds in EGFR and VEGFR were performed using AutoDock Vina. Visualization of the docking results was performed by using Biovia Discovery Studio Visualizer to observe the bond interactions that occur between ligands and receptors, and as well as the residues which are directly involved in the interaction process. ${ }^{21}$

\section{RESULTS AND DISCUSSION}

The receptors EGFR and VEGFR used in this study were obtained through the Research Collaboratory for Structural Bioinformatics (RCSB) protein data bank (PDB) website with protein data bank (PDB) codes of 5HG7 and 4AG8. Selection of the receptors were based on experimental data, with the organism name as Homo sapiens (human) and resolution values less than $3.0 \AA$. The resolution value and organism name are the parameters in receptor selection. Molecular docking using a receptor with a lower resolution value will indicate a better receptor stability. ${ }^{22}$

Preliminary pharmacology activity prediction of the test compounds listed above was done by inserting the Simplified Molecular Input Line Entry System (SMILES) of the compounds to Prediction of Activity Spectra for Substances (PASS) website. The pharmacology activity prediction results of test compounds and standard compound can be seen in Table 1.

The results showed that the test compounds have these main pharmacology activities: antineoplastic, apoptosis agonist, and cytostatic. The three main activities of the test compounds have anticancer effects. Antineoplastic drugs are antiproliferative, anticancer drugs that can affect the process of cell division by damaging the deoxyribonucleic acid (DNA) which prevents the development and the spread of cancer cells. ${ }^{23}$ Cytostatic effects inhibit and kill cancer cells in the body..$^{24}$ Apoptosis is an important mechanism for preventing cancer cell proliferation and serving as one of the control checkpoints in the cell cycle. ${ }^{25}$ The test compounds shown the high anticancer activity that were not significantly different than in the standard compound. The compounds that provide anticancer activity with probable activity of more than 0.7 are categorized as active compounds. ${ }^{26}$

Validation of the method and re-docking was done by using the AutoDock Vina program between the original ligand from the crystal structure of respective receptors through the evaluation of the root mean square deviation (RMSD) values. The results of the redocking analysis will give a RMSD values. In this study, the values obtained were $1.7818 \AA$ for EGFR and $1.6819 \AA$ for VEGFR. This means that the method used is accepted according to the standard root mean square deviation (RMSD) value which is less than $2.0 \AA .^{27}$

Molecular docking is one of the in silico techniques which predicts the mechanism of interaction of binding site between a ligand and a

Table 1: The pharmacology activity prediction results of test compounds and standard compound.

\begin{tabular}{lll}
\hline Compound & Activity & Probable Activity \\
Vernodalol & Antineoplastic & 0.949 \\
& Apoptosis Agonist & 0.748 \\
Vernodalin & Antineoplastic & 0.960 \\
Vernolepin & Apoptosis Agonist & 0.845 \\
& Antineoplastic & 0.960 \\
Vernomygdin & Apoptosis Agonist & 0.749 \\
& Antineoplastic & 0.967 \\
Vernolide & Apoptosis Agonist & 0.858 \\
& Cytostatic & 0.840 \\
& Cytostatic & 0.948 \\
Hydroxyvernolide & Antineoplastic & 0.943 \\
& Apoptosis Agonist & 0.911 \\
& Antineoplastic & 0.972 \\
Cyclophosphamide & Apoptosis Agonist & 0.910 \\
& Cytostatic & 0.906 \\
& Antineoplastic & 0.996
\end{tabular}



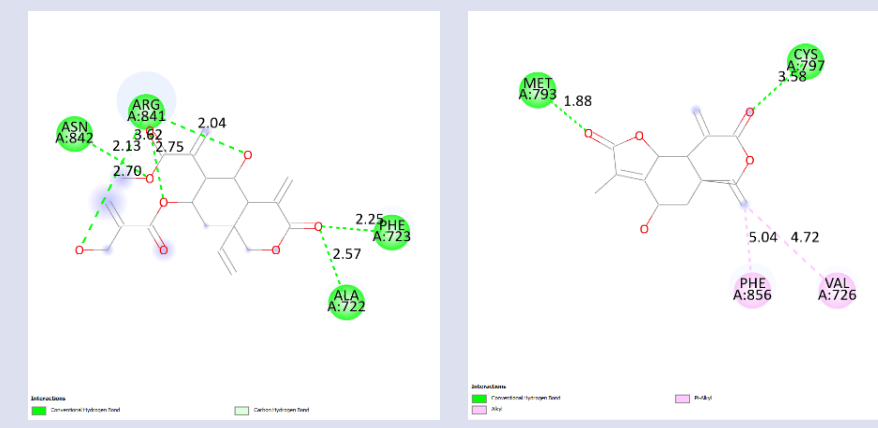

A-1

B-1
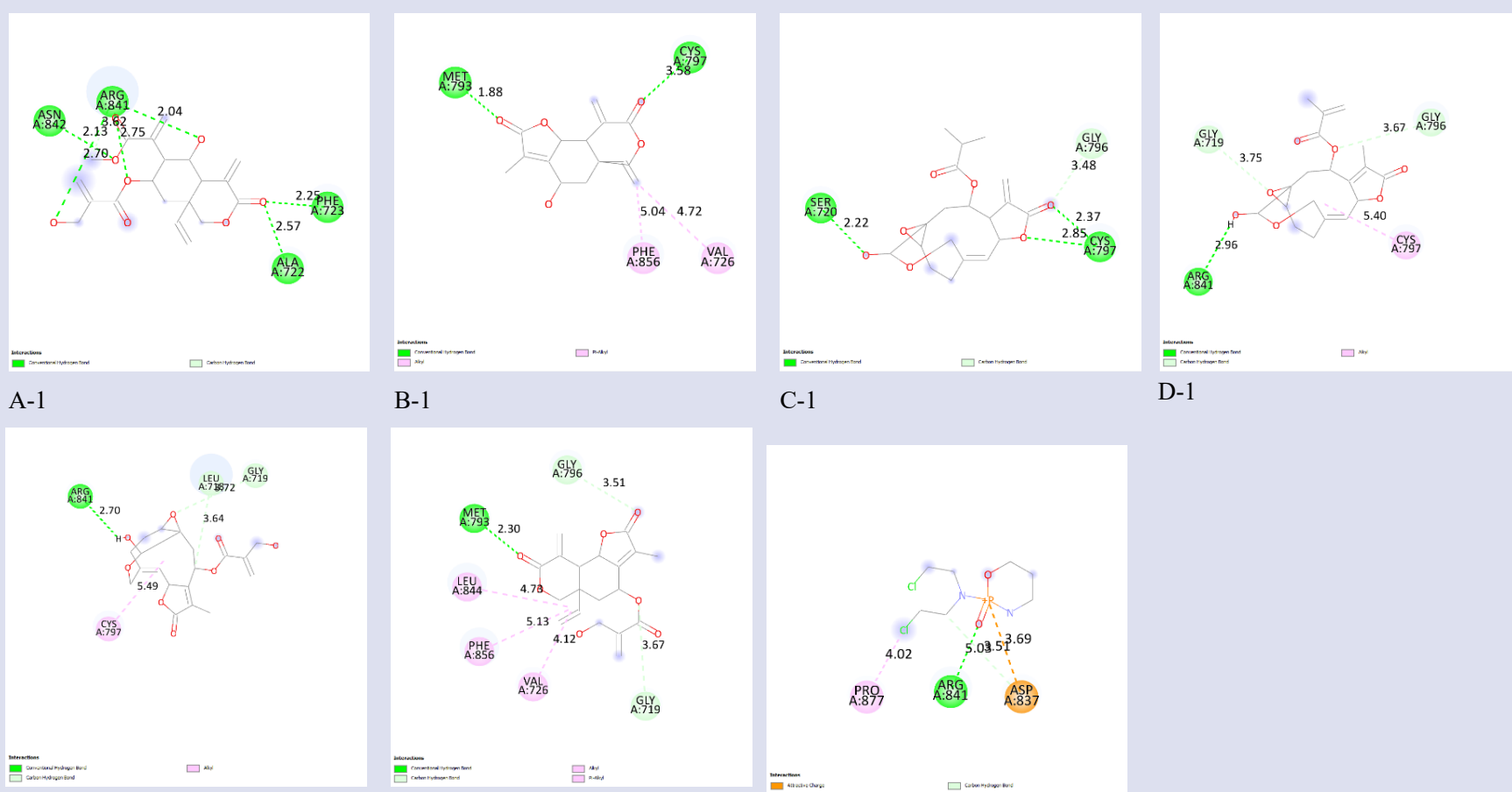

C-1

D-1

E-1

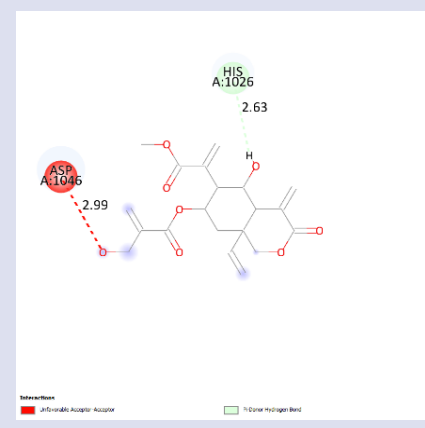

A-2

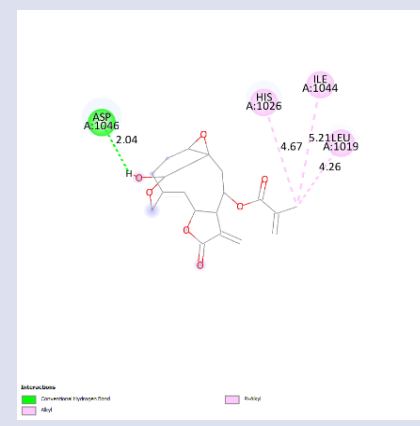

E-2

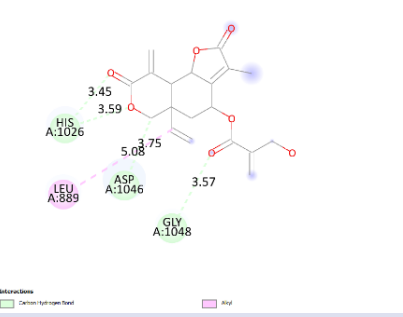

B-2

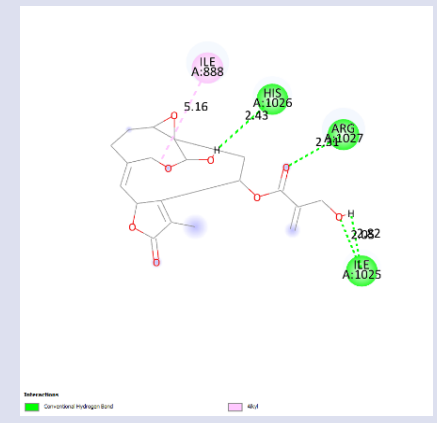

F-2

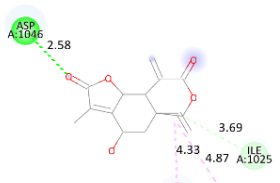

A.

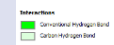

C-2

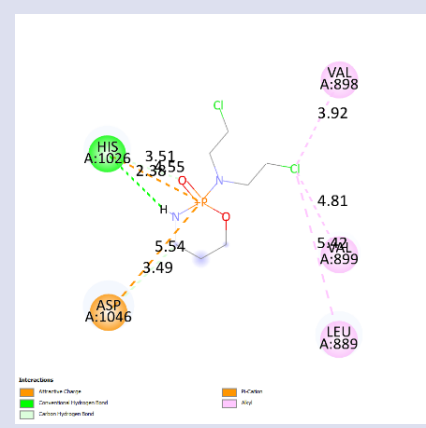

G-2

Figure 1: The distance and interaction of amino acid residue with test compounds and standard compound against EGFR and VEGFR. *A: vernodalol; B: vernodalin; C: vernolepin; D: vernomygdin; E: vernolide; F: hydroxyvernolide; G: cyclophosphamide; 1: EGFR; 2: VEGFR. 
Table 2: The docking score and interaction of amino acid residue with test compounds and standard compound against EGFR and VEGFR.

\begin{tabular}{|c|c|c|c|}
\hline Protein & Ligand & $\begin{array}{l}\text { Docking Score } \\
\text { (Kcal per Mol) }\end{array}$ & $\begin{array}{l}\text { Interaction Amino } \\
\text { Acid Residue }\end{array}$ \\
\hline \multirow{6}{*}{ EGFR } & Vernodalol & -6.4 & $\begin{array}{l}\text { Ala } 722 \text {, Phe } 723 \text {, } \\
\text { Arg } 841 \text {, Asn } 842 \text {, }\end{array}$ \\
\hline & Vernodalin & -8.0 & $\begin{array}{l}\text { Val 726, Met } 793 \text {, } \\
\text { Cys } 797 \text {, Phe } 856\end{array}$ \\
\hline & Vernolepin & -7.9 & $\begin{array}{l}\text { Ser } 720 \text {, Gly } 796 \text {, } \\
\text { Cyc } 797\end{array}$ \\
\hline & Vernomygdin & -7.6 & $\begin{array}{l}\text { Gly } 719, \text { Gly } 796, \\
\text { Cys } 797 \text {, Arg } 841\end{array}$ \\
\hline & Vernolide & -7.8 & $\begin{array}{l}\text { Leu } 718, \text { Gly } 719 \text {, } \\
\text { Cys 797, Arg } 841\end{array}$ \\
\hline & Hydroxyvernolide & -7.8 & $\begin{array}{l}\text { Gly } 719 \text {, Val } 726 \text {, } \\
\text { Met } 793 \text {, Gly } 796 \text {, } \\
\text { Leu } 844 \text {, Phe } 856\end{array}$ \\
\hline \multirow{8}{*}{ VEGFR } & Cyclophosphamide & -4.8 & $\begin{array}{l}\text { Asp 837, Arg 841, } \\
\text { Pro } 877\end{array}$ \\
\hline & Vernodalol & -6.9 & His 1026, Asp 2046 \\
\hline & Vernodalin & -7.4 & $\begin{array}{l}\text { Leu } 889, \text { His } 1026 \text {, } \\
\text { Asp } 1046 \text {, Gly } 1048\end{array}$ \\
\hline & Vernolepin & -7.5 & $\begin{array}{l}\text { Ile } 888 \text {, Cys } 1024 \text {, } \\
\text { Ile } 1025 \text {, Asp } 1046\end{array}$ \\
\hline & Vernomygdin & -8.0 & $\begin{array}{l}\text { Leu } 1019 \text {, His } 1026 \text {, } \\
\text { Ile } 1044\end{array}$ \\
\hline & Vernolide & -8.1 & $\begin{array}{l}\text { Leu 1019, His 1026, } \\
\text { Ile 1044, Asp } 1046\end{array}$ \\
\hline & Hydroxyvernolide & -7.6 & $\begin{array}{l}\text { Ile } 888 \text {, Ile } 1025 \text {, } \\
\text { His } 1026 \text {, Arg } 1027\end{array}$ \\
\hline & Cyclophosphamide & -5.0 & $\begin{array}{l}\text { Leu } 889, \text { Val } 898 \text {, } \\
\text { Val } 899, \text { His } 1026 \text {, } \\
\text { Asp } 1046\end{array}$ \\
\hline
\end{tabular}

target protein..$^{28}$ The affinity of the binding is measured by the value of docking scores. As a potential medication candidate, a molecule with a lower binding energy is always preferred. ${ }^{29}$ There are several cell biology markers associated with apoptosis and angiogenesis, including EGFR and VEGFR. ${ }^{30}$ Activation of EGFR and VEGFR will induce various important cellular responses such as increased angiogenesis, increased tumor survival, increased cell proliferation, decreased apoptosis, increased invasion and increased metastasis. ${ }^{31}$ Both EGFR and VEGFR have the potential ability to repair the DNA of tumor cells damaged by chemotherapy. ${ }^{32}$ Thus, the success of cancer treatment can be increased by inhibiting EGFR and VEGFR. ${ }^{33}$

The test compounds were docked with EGFR and VEGFR to obtain the docking score values with AutoDock Vina. These docking score values were compared to the standard compound. This was done to compare whether the test compounds have a better or worse activity compared to the standard compound. Table 2 showed the docking score and interaction of amino acid residue with the test compounds and standard compound against EGFR and VEGFR. Figure 1 shows the distance and interaction of amino acid residue with the test compounds and standard compound against EGFR and VEGFR.

The results showed that the overall docking scores of test compounds against EGFR and VEGFR were lower than the docking score of the standard anticancer drug (cyclophosphamide). This phenomenon also shows that test compounds have better activity of inhibition of EGFR and VEGFR compared to standard compound. The value of free energy produced when the receptor-ligand complex that is formed can indicate the affinity of the ligand for the receptor. If the affinity of the ligand to the receptor is high, the free energy value or docking score decreases. Alternatively, if the affinity is small, the free energy value or docking score increases. ${ }^{34}$
The results showed that various amino acid residues on the EGFR and VEGFR have interactions with test compounds and standard compound against EGFR and VEGFR. The overall interaction has a distance between the ligand and the amino acid residue of the receptor which is less than $6.0 \AA$. A distance of less than $12.0 \AA$ indicates a good interaction between the ligand and the amino acid residue of the receptor. $^{35}$

Cyclophosphamide is often used as first-line cancer therapy. ${ }^{36}$ The existence of side effects from the use of chemotherapy drugs and resistance of cancer cells to chemotherapy drugs is a challenge in cancer treatment. ${ }^{37}$ Serious problems in side effects and resistance to chemotherapy drugs drive the need for new chemotherapy drugs that are safer and more effective. ${ }^{38}$ The search for anticancer drugs from natural ingredients has great potential for the discovery of new treatment options. The results showed that the use of natural ingredients had lower side effects and could still optimize the selectivity of cancer treatment. ${ }^{39}$ Extracts of natural ingredients contain various phytochemicals in varying amounts, and have been shown to have a synergistic effect. Thus, the expected minimal dose or concentration can provide maximum effect. ${ }^{40}$

\section{CONCLUSION}

The intention of this study is to discover a potent inhibitor of EGFR and VEGFR expression as a possible anticancer targeted therapy through in silico methods. The results of this study show that the binding energy as well as interactions of test compounds with EGFR and VEGFR were promising for future research for their use in anticancer drugs. This research can be continued by carrying out in vitro and in vivo investigations to confirm the physiological implications of these findings.

\section{AUTHORS CONTRIBUTION}

Contribution of the authors in: conceptualization, N.N. and S.A.b.A.; methodology, N.N. and S.A.b.A.; resources, N.N. and S.A.b.A.; writing the original draft preparation, N.N. and S.A.b.A.; writing the review and editing, N.N.; visualization, N.N.; supervision, E.D.P.; project administration, F.F., P.L. and F.Y.; funding acquisition, N.N., P.L., S.A.b.A. and F.Y. All authors have read and agreed to the published version of the manuscript.

\section{CONFLICTS OF INTEREST}

The authors declare no conflicts of interest in this research and no conflicts of interest in this manuscript.

\section{REFERENCES}

1. Kumara M, Shylajab MR, Nazeemc PA, Babu T. 6-Gingerol is the Most Potent Anticancerous Compound in Ginger (Zingiber officinale Rosc.). Journal of Developing Drugs. 2017;6(1):167.

2. Iheagwam FN, Israel EN, Kayode KO, De Campos OC, Ogunlana OO, Chinedu SN. Nauclea latifolia Sm. Leaf Extracts Extenuates Free Radicals, Inflammation, and Diabetes-Linked Enzymes. Oxidative Medicine and Cellular Longevity. 2020;3:5612486.

3. Siegel RL, Miller KD, Jemal A. Cancer Statistics, 2021. CA: A Cancer Journal for Clinicians. 2021;71:7-33

4. Kannaiyan R, Mahadevan D. A Comprehensive Review of Protein Kinase Inhibitors for Cancer Therapy. Expert Review of Anticancer Therapy. 2018;18(12):1249-1270.

5. Seebacher NA, Stacy AE, Porter GM, Merlot AM. Clinical Development of Targeted and Immune Based Anti-Cancer Therapies. Journal of Experimental and Clinical Cancer Research. 2019;38(4):156

6. Wee P,Wang Z. Epidermal Growth Factor Receptor Cell Proliferation Signaling Pathways. Cancers. 2017:9(5):52. 
7. Zakaria Z, Zulkifle MF, Hasan WANW, Azhari AK, Raub SHA, Eswaran $J$, et al. Epidermal Growth Factor Receptor (EGFR) Gene Alteration and Protein Overexpression in Malaysian Triple-Negative Breast Cancer (TNBC) Cohort. Onco Targets and Therapy. 2019;12:7749-77.

8. Pauty J, Usuba R, Cheng IG, Hespel L, Takahashi H, Kato K, et al. A Vascular Endothelial Growth Factor-Dependent Sprouting Angiogenesis Assay Based on an In Vitro Human Blood Vessel Model for the Study of Anti-Angiogenic Drugs. EBioMedicine. 2018;27(01):225-236

9. Yang J, Yan J, Liu B. Targeting VEGF/NEGFR to Modulate Antitumor Immunity. Journal of Frontiers in Immunology. 2018;9(5):1.

10. Lopes-Coelho F, Martins F, Pereira SA, Serpa J. Anti-Angiogenic Therapy: Current Challenges and Future Perspectives. International Journal of Molecular Sciences. 2021;22(4):3765.

11. Cragg GM, Pezzuto JM. Natural Products as a Vital Source for the Discovery of Cancer Chemotherapeutic and Chemopreventive Agents. Medical Principles and Practice. 2016;25(2):41-59.

12. Chiocchio I, Mandrone M, Tomasi P, Marincich L, Poli F. Plant Secondary Metabolites: An Opportunity for Circular Economy. Molecules. 2021;26(1):495.

13. Ugbogu EA, Emmanuel O, Dike ED, Agi GO, Ugbogu OC, Ibe C, et al. The Phytochemistry, Ethnobotanical, and Pharmacological Potentials of the Medicinal Plant-Vernonia amygdalina L. (bitter Leaf). Clinical Complementary Medicine and Pharmacology. 2021;1(1):100006.

14. Kunnumakkara AB, Bordoloi D, Sailo BL, Roy NK, Thakur KK, Banik K, et al. Cancer Drug Development: The Missing Links. Experimental Biology and Medicine. 2019;244(4):663-689.

15. Sinisi A, Millán E, Abay S, Habluetzel A, Appendino G, Muñoz E, et al. Poly-Electrophilic Sesquiterpene Lactones from Vernonia amygdalina: New Members and Differences in Their Mechanism of Thiol Trapping and in Bioactivity. Journal of Natural Products. 2015;78(7):1618-1623.

16. Nerdy N, Margata L, Meliala L, Purba JS, Sembiring BM, Ginting S, et al. In Silico Evaluation of the Physicochemical, Pharmacokinetics, and Toxicity Profiles of Sesquiterpene Lactones of South African Leaf (Vernonia amygdalina Delile). Tropical Journal of Natural Product Research. 2021;5(10):1835-1840.

17. Hosen MA, Alam A, Islam M, Fujii $Y$, Ozeki $Y$, Kawsar SMA. Geometrical Optimization, PASS Prediction, Molecular Docking, and In Silico ADMET Studies of Thymidine Derivatives against FimH Adhesin of Escherichia coli. Bulgarian Chemical Communications. 2021;53(3):327-342.

18. Ong JH, Koh JA, Cao H, Tan SA, Manan FA, Wong FC, et al. Purification, Identification and Characterization of Antioxidant Peptides from Corn Silk Tryptic Hydrolysate: An Integrated In VitroIn Silico Approach. Antioxidants. 2021;10(11):1822.

19. Shakil S, Rizvi SMD, Greig NH. High Throughput Virtual Screening and Molecular Dynamics Simulation for Identifying a Putative Inhibitor of Bacterial CTX-M-15. Antibiotics. 2021;10(4):474.

20. Martins FG, Melo A, Sousa SF. Identification of New Potential Inhibitors of Quorum Sensing through a Specialized Multi-Level Computational Approach. Molecules. 2021;26(9):2600.

21. Sivani BM, Venkatesh P, MurthyTPK, Kumar B. In Silico Screening of Antiviral Compounds from Moringa oleifera for Inhibition of SARSCoV-2 Main Protease. Current Research in Green and Sustainable Chemistry. 2021;4(10):100202.

22. Yin YL, Ye C, Zhou F, Wang J, Yang D, Yin W, et al. Molecular Basis for Kinin Selectivity and Activation of the Human Bradykinin Receptors. Nature Structural \& Molecular Biology. 2021;28(9):755-761.
23. Choudhari AS, Mandave PC, Deshpande M, Ranjekar P, Prakash O. Phytochemicals in Cancer Treatment: From Preclinical Studies to Clinical Practice. Frontiers in Pharmacology. 2020;10(1):1614.

24. Heymans V, Kunath S, Hajieva P, Moosmann B. Cell Culture Characterization of Prooxidative Chain-Transfer Agents as Novel Cytostatic Drugs. Molecules. 2021;26(21):6743.

25. Mathiassen SG, De Zio D, Cecconi F. Autophagy and the Cell Cycle: A Complex Landscape. Frontiers in Oncology. 2017;7(3): 51.

26. Lagunin AA, Dubovskaja VI, Rudik AV, Pogodin PV, Druzhilovskiy DS, Gloriozova TA, et al. CLC-Pred: A Freely Available Web-Service for In Silico Prediction of Human Cell Line Cytotoxicity for Drug-Like Compounds. Plos One. 2018;13(1):e0191838.

27. Xiao W, Wang D, Shen Z, Li S, Li H. Multi-Body Interactions in Molecular Docking Program Devised with Key Water Molecules in Protein Binding Sites. Molecules. 2018;23(9):2321.

28. Maia EHB, Assis LC, Oliveira TAD, Silva AMD, Taranto AG. StructureBased Virtual Screening: From Classical to Artificial Intelligence. Frontiers in Chemistry. 2020;8(4):343.

29. Nisha CM, Kumar A, Nair P, Gupta N, Silakari C, Tripathi T, et al. Molecular Docking and In Silico ADMET Study Reveals Acylguanidine $7 a$ as a Potential Inhibitor of $\beta$-Secretase. Advances in Bioinformatics. 2016;2016(3):9258578.

30. Wang X, Bove AM, Simone G, Ma B. Molecular Bases of VEGFR-2Mediated Physiological Function and Pathological Role. Frontiers in Cell and Developmental Biology. 2020;8(11):599281.

31. Lee SH, Jeong D, Han YS, Baek MJ. Pivotal Role of Vascular Endothelial Growth Factor Pathway in Tumor Angiogenesis. Annals of Surgical Treatment and Research. 2015;89(1):1-8.

32. Falzone L, Salomone S, Libra M. Evolution of Cancer Pharmacological Treatments at the Turn of the Third Millennium. Frontiers in Pharmacology. 2018;9(11):1300.

33. Kaufman NEM, Dhingra S, Jois SD, Vicente MdGH. Molecular Targeting of Epidermal Growth Factor Receptor (EGFR) and Vascular Endothelial Growth Factor Receptor (VEGFR). Molecules. $2021 ; 26(4): 1076$

34. Pantsar T, Poso A. Binding Affinity via Docking: Fact and Fiction. Molecules. 2018;23(8):1899.

35. Fu Y, Zhao J, Chen Z. Insights into the Molecular Mechanisms of Protein-Ligand Interactions by Molecular Docking and Molecular Dynamics Simulation: A Case of Oligopeptide Binding Protein. Computational and Mathematical Methods in Medicine. 2018;12:3502514.

36. Škubník J, Pavlícková VS, Ruml T, Rimpelová S. Vincristine in Combination Therapy of Cancer: Emerging Trends in Clinics. Biology. 2021;10(9):849.

37. Zhong $L$, Li $Y$, Xiong $L$, Wang $W, W u ~ M$, Yuan $T$, et al. Small Molecules in Targeted Cancer Therapy: Advances, Challenges, and Future Perspectives. Signal Transduction and Targeted Therapy. 2021;6(5):201.

38. Waldman AD, Fritz JM, Lenardo MJ. A Guide to Cancer Immunotherapy: from T Cell Basic Science to Clinical Practice. Nature Reviews Immunology. 2020;20(5):651-668.

39. Atanasov AG, Zotchev SB, Dirsch VM, Taskforce INPS, Supuran CT. Natural Products in Drug Discovery: Advances and Opportunities. Nature Reviews Drug Discovery. 2021;20(1):200-216.

40. Havelt $T$, Brettschneider S, Schmitz M. Evaluation of Practical Applicability and Synergistic Effects of Bio-Based Food Packaging Materials Combined with Plant-Based Stabilisers. Processes. 2021;9(10):1838 


\section{GRAPHICAL ABSTRACT}

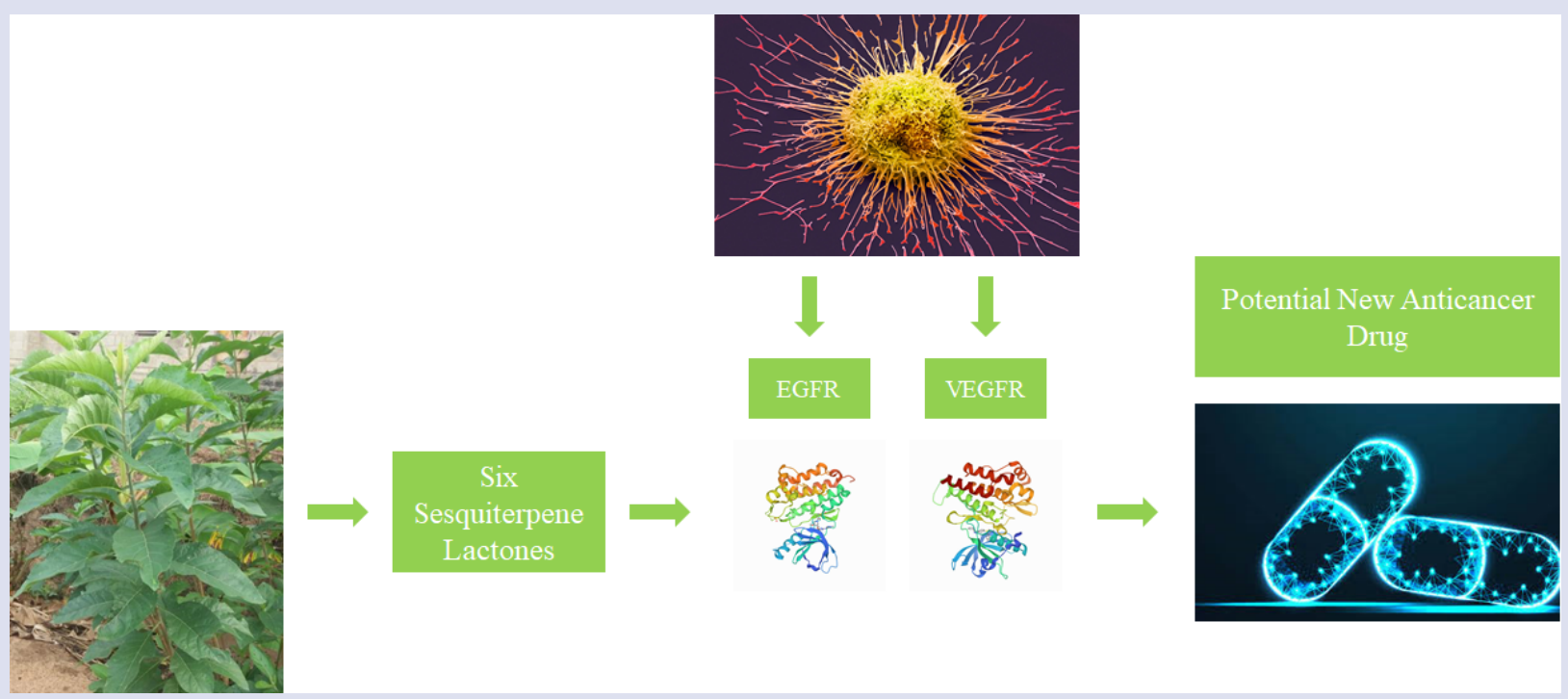

\section{ABOUT AUTHORS}
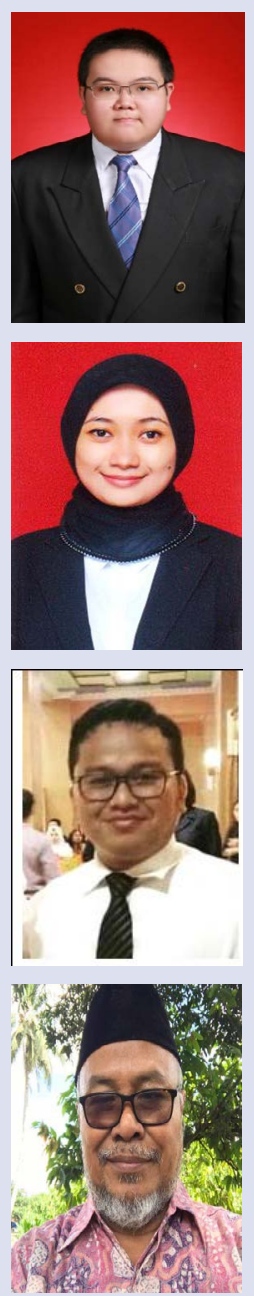

Nerdy Nerdy has been a doctoral in the pharmaceutical field and associate professor at the Faculty of Pharmacy, Institut Kesehatan Deli Husada Deli Tua since 2019. His research fields are pharmaceutical chemistry, biology, technology, and pharmacology.

Puji Lestari is a Bachelor of Pharmacy and a master of science from Universitas Sumatera Utara. She joined the Faculty of Pharmacy, Institut Kesehatan Deli Husada Deli Tua in 2019 as a lecturer in pharmacology and toxicology.

Firdaus Fahdi is a lecturer at the Faculty of Pharmacy, Institut Kesehatan Deli Husada Deli Tua. His research scope ranges from pharmacology to natural product and biology pharmacy.

Effendy De Lux Putra is a professor at the Faculty of Pharmacy Universitas Sumatera Utara. His research field is pharmaceutical chemistry, especially pharmaceutical analysis and medicinal chemistry. 


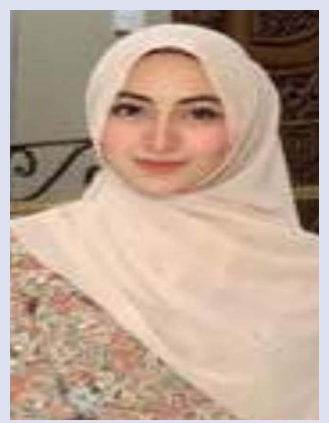

Siti Amira Binti Amir is a student at Faculty of Pharmacy, Universitas Sumatera Utara. Her research field is the pharmaceutical analysis and medicinal chemistry.



Faisal Yusuf is a pharmacist and a Master of Management degree; currently, the research focuses on developing a product from natural products and the management of pharmaceutical products. He joined the Faculty of Pharmacy, STiKes Arjuna Laguboti as lecturer of pharmacy.

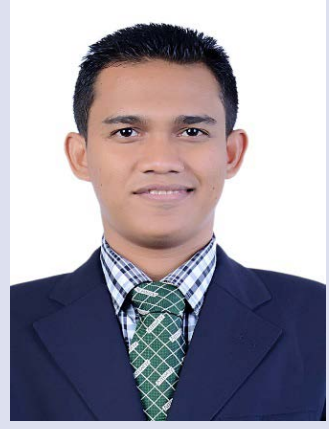

Tedy Kurniawan Bakri is a lecturer at the Department of Pharmacy, Faculty of Mathematics and Natural Sciences, Universitas Syiah Kuala. He also serves as a clinical pharmacist in Aceh Mental Hospital. His research scope ranges from pharmacology to clinical pharmacy.

Cite this article: Nerdy N, Lestari P, Fahdi F, Putra EDL, Amir SAB, Yusuf F, et al. In Silico Studies of Sesquiterpene Lactones from Vernonia amygdalina Delile on the Expression of EGFR and VEGFR as a New Anticancer Potential. Pharmacogn J. 2022;14(1): 91-97. 